\title{
Degree of Verification of "CAEP" standards Concerning Graduates of School of Educational Sciences from their Point of View at University of Jordan
}

\begin{abstract}
Dr.Sanaa Yousef Majdalawieh
Faculty of School of Educational Sciences at University of Jordan

Abstract

The purpose of this study is to determine the degree of verification of CAEP standards for the preparation of teachers and concerning graduates of School of Educational Sciences at University of Jordan. To achieve the goal of the study, the CAPE standards were applied. CAEP standards are five : (1) Understanding and addressing each child's developmental and learning needs, (2) Understanding and Applying Content and Curricular Knowledge for Teaching, (3) Assessing, Planning, and Designing Contexts for Learning, (4) Supporting Each Child's Learning Using Effective Instruction, and (5) Developing as a Professional. The sample of the study consisted of all graduates from the specialty of classroom teacher and child education who graduates in the first semester of the academic year 2018-2019. The results of the study show that the degree of verification of CAEP standards was medium-level. There are no statistically significant differences between students due to specialization , cumulative average at university, rate in high school. The results show that there is a positive correlation between the desire to specialization and the degree of verification of CAEP standards. The author recommend that university develops its academic programs for teacher preparation to meet CAEP standards. The study also recommend that the acceptance policy of students must be developed to accept those with strong desire in teaching profession in addition to high average in high school .
\end{abstract}

Keywords: CAEP, Jordan, Students, Teachers, Standards

DOI: $10.7176 / \mathrm{JEP} / 11-12-17$

Publication date: April $30^{\text {th }} 2020$

\section{Introduction}

Education is an important tool for the development of societies. It is the engine to evolution of the world and the standard for everyone's progress. Education develops individuals' capacities, refines people's personalities and enables problems solving ability. Teachers are responsible for teaching young people and put them in front of different challenges. There is a growing interest in the preparation of teachers in the developed countries and developing countries in response to the belief that teachers are important for education process and community development. And if the teacher is the main entry point for any development in education, a good preparation for the teacher is the main issue that should be focused on and attention to, "Just as students are affected by what the teacher provides of education; teachers are affected by the training provided to them, and knowing this truth and understanding The importance of teachers, makes their preparation process of paramount importance for all society (Armstrong, 2007). The teacher preparation programs are also important (Ababneh, 2015), especially in the areas of scientific, cultural and professional aspects (Douiri, 2015).

Also it is confirmed that International Education scenarios presented by UNESCO teachers must have good preparation before-the-service and follow- up training (Hammoud, 1997). Institutions must prepare teachers with qualified academically and professionally and behavioral knowledge (Da'jah and Saiadh et al. , 2011). It is worth mentioning that the quality of training that received by the teachers is directly related to their performance (Hamdan, 1997). The lack of ability of some teachers may be caused by limited preparation (David, 2002). The students may have little chance to achieve higher level than the level of teachers (Hogginson1996: 27). To sum up, the evaluation and development of preparation programs are important and urgent. Evaluation of institutions for preparing the teacher includes evaluating the performance of students and the performance of staff members (Saud, 2002). The quality assurance in education means the ability of the institution to provide decent service level so that the students' performance can meet their needs and desires (Khatib, 2007). Higher systems of educational service, such as universities, may emphasize the quality of education by providing and adopting new preparation methods (Canaan, 2009). It called for many researchers to develop or adopt standards to ensure the preparation quality (Odeh , 2011), (Al- Dahshan , 2013).

Therefore, local and international institutions need to maintain culture of excellence and ensure quality. The Council for the Accreditation of Educato $r$ Preparation (CAEP) is one of the most important and recent educational accreditation bodies that are responsible for accrediting specialized educational programs in the United States of America. It was established as a result of the merger of National council for Accreditation of Teacher Education, ( NCATE) Teacher Education Accreditation Council, (TEAC) in the year 2010. The council's mission included a 
distinguished preparation for educators through evidence-based accreditation and continuous development of students. The academic accreditation of educational institutions began in the last century in America, with the aim of raising the level of education and ensuring its quality. The same happened in United Kingdom, Japan , Australia, and New Zealand.

The Arab world has about 1400 universities with 15 million students.Therefor the Federation of Arab Universities established the Quality Assurance and Accreditation Council for Arab Universities to develop higher education and improve its quality (Abu Orabi, 2018).In Jordan, as a result of the growing demand for higher education, the emergence and growth of private universities, globalization and its challenges and the desire to ensure the quality of higher education, a committee was established to accredit higher education institutions in 1990, then the Commission for Accreditation of Higher Education Institutions was established and its quality assured in 2007 to be the first responsible national reference On developing and improving the quality and quality of higher education.

Philosophy of teacher preparation programs (UNESCO Report 2017) Teacher preparation programs are designed to prepare teachers according to the educational and psychological theories with expertise and scientific, professional and cultural knowledge. It emphasizes the philosophy of the preparation that a good teacher is the basic component of education and that achieves the goals and development of the society. The philosophy of preparation programs is related to the needs of learners. The teacher preparation programs have evolved in terms of the foundations of their construction from programs based on objectives, to programs based on competencies, then to standards-based preparation programs.

Obgectives-Based Preparation :This model depends on showing behavior or performance expected from the learner after completion the process of learning. It focuses on the knowledge side and neglect other aspects, which led to the emergence of the need for other alternatives, such as preparation based on competencies or preparation based on standards.

Competency-Based Preparation: Adequacy is a term that describes what a graduate must master in order to carry out his profession, which is the ability of the teacher to perform his educational tasks with a certain level of performance that guarantees the improvement of the required educational outcome.. It is expected that preparing the teacher based on the competencies enables teachers to adapt the content from textbooks and make them easy to be learned.

Standards-based preparation: Standards are the most important and most recent educational reform movement in the world and are the primary element in the development of all components of educational programs and their practices. Standards for teacher preparation are defined as expressions that define what the teacher must know and be able to perform and implement.

Quality of teacher preparation programs and preparation standards: UNESCO defined quality in higher education at the conference held in Paris in 1998, as a multidimensional concept that includes all educational functions and activities. It includes following up the specifications and conditions that must be met in the teacher preparation programs, which are the quality of management, admission policies and all What includes objectives, content, teaching methods and evaluation, in addition to what the agencies responsible for ensuring the quality of teacher preparation programs do.It is also defined that standards in teacher performance as a set of characteristics that must be met ( Weh , 2003). Researchers also indicated that the standard level developed is important for achieving a degree desirable of quality or excellence (Dahshan 2013).Kaabi (2004) argued that the standards in education are important for educators, parents and local ommunity to evaluate the performance of students and institutions. As confirmed by Eldredge (2016).

\section{CAEP 2018 K-Elementary Teacher Preparation Standards}

CAEP Accreditation Council is an international organization concerned with preparing educators, and works to provide consultations and support to educational institutions to obtain academic and professional accreditation. This organization appeared in 2010 as a result of the merger of two important institutions in the field of preparing educators and accreditation of preparation institutions, namely: NCATE And the TEAK Foundation.

In view of the reputation and importance of this institution in the world, the educational colleges in the United States of America and the world have endeavored to achieve the accreditation standards issued by them to ensure obtaining a certificate proving excellence, and competitiveness. On the Arab level, the United Arab Emirates University has obtained educational accreditation from theCAEP Foundation. The School of Educational Sciences at the University of Jordan is currently seeking academic accreditation from this institution. 
Standards for the preparation of primary school teachers: In 2018, the Steering Committee of the Accreditation Council for Teacher Training Institutions presented a modified version of a set of criteria for the preparation of primary school teachers, and these criteria defined what graduates should know and what they should be able to do at the end of the preparation. The new standards require elementary school teachers new knowledge and skills to be able to practice effectively. They also require new ways of thinking about the development of children, families and societies, and a deep knowledge of the content needed to teach language, mathematics, science and social studies. Also, knowledge of motivation ,participation,professional development and the ability to work cooperatively with a wide range of colleques and professionals. Below is an explanation of these standards.

Standard 1 - Understanding and Addressing Each Child's Developmental and Learning Needs

The CAEP 2018 K-6 Elementary Standard 1 contains three components that focus on knowledge of child growth and development, using understanding of individual differences and diverse families and communities, and working respectfully and reciprocally with families, colleagues and school and other professionals. This standard now includes strong emphasis on using knowledge of child growth and development in planning, implementing, and assessing learning experience and environments. Finally, Standard 1 now includes an emphasis on working effectively with families based on respectful and reciprocal relationships.

Standard 2 - Understanding and Applying Content and Curricular Knowledge for Teaching The CAEP 2018 K6 Elementary Standard 2-the subject matter content standard-now includes four components that focus on the content areas of literacy, mathematics, science, and social studies, and requires beginning K-6 teachers to possess deeper content knowledge than previously expected, as well as a deeper understanding of digital learning. There is also greater emphasis on candidate ability to make purposeful connections between or across the curricular areas of literacy, mathematics, science, and social studies.

Standard 3 - Assessing, Planning, and Designing Contexts for Learning

The CAEP 2018 K-6 Elementary Standard 3 focuses on assessing, planning, and designing contexts for learning. Six components are defined including assessment and using assessment data, planning for instruction and differentiation of instruction, managing the classroom-learning environment, and supporting student motivations and engagement in learning.

Standard 4 - Supporting Each Child's Learning Using Effective Instruction.

The CAEP 2018 K-6 Elementary Standard 4 is defined by seven component statements that demonstrate a narrow but deep focus on knowledge-based, high leverage instructional practices. This standard reflects a less is more perspective as candidates need to demonstrate greater competence in a few key areas rather than minimal exposure to many instructional strategies. The 2018 Standard 4 also includes a greater emphasis on meeting the learning needs of each child, as well as a much enhanced and targeted focus on motivation and engagement.

Standard 5 - Developing as a Professional.

The CAEP 2018 K-6 Elementary Standard 5 is comprised of three components organized around collaboration, professional learning, and professional learning communities. .

The statement of the problem and its questions

The statement of the problem is summarized in answering the following questions:

1. What is the degree of verification of CAEP standards among graduates from the School of Educational Sciences at the University of Jordan?

2. Are there statistically significant differences (at the level of $\alpha \leq 0.05$ ) in the degree of verification of CAEP standards among the graduates from School of educational Sciences at the university of Jordan due to the specialization?

3 - Is there a statistically significant correlation (at $\alpha \leq 0.05$ ) between the degree of verification of CAEP standards among graduates of the School of Educational Sciences and their levels in high school?

4. Is there a statistically significant correlation (at $\alpha \leq 0.05$ ) between the degree of verification of CAEP standards among graduates from the School of Educational Sciences and their cumulative rates at the university?

5 - Is there a statistically significant correlation (at $\alpha \leq 0.05$ ) between the degree of verification of CAEP standards among graduates from the School of Educational Sciences and their desire in the specialization at the university?

\section{Objectives and importance of the study}

School of Educational Sciences at the University of Jordan is to get the General accreditation of the Council of the adoption of the institutions of the preparation of teachers, which will give the college and university more of the credibility and reputation. It will increase degree of competitiveness of the college and its graduates.

\section{The aim of this study to determine}

The purpose of this study is to determine the degree of verification of CAEP standards for the preparation of teachers from their own point of view, and to reveal all aspects of the strengths and weakness in the program. It 
aims also to the disclose the relationship between the degree of verification of CAEP standards and the following variables: specialization, average in high school, ccumulative average in the university, their desire in specialization.It is hoped that the results of this study will be beneficial to the college in terms of program development according to the criteria of the CAEP standards.

\section{Key terms in this study.}

Academic Accreditation: Procedurally defined as granting a certificate from a recognized body confirming that the educational program or educational institution meets the standards required for accreditation.

Criteria for Accrediting Teacher Preparation: The Criteria for Accrediting Teacher Preparation in this study means the standards issued by the CAEP Institution for Preparation of Primary Stage Teachers in 2018.

CAEP: It is an acronym for the Council for the Accreditation of Educator Preparation, a prestigious global body for accreditation for educational institutions.

Degree of verification of standards: The degree of verification of standards is defined by the degree of assessment of the sample for practicing the performance criteria and indicators mentioned in the study tool.

\section{Limits of the study}

- The objectives of this study were limited to determining the degree to which the (KEP) criteria are met for the preparation of primary school teachers for the year 2018 and their relationship to some variables. Issued for the Council to adopt institutions of the preparation of teachers (CAEP) in the US in 2018.

- It is limited to investigate the of alumni of semester 2019/2020 at the Faculty of Science Education University of Jordan.

- The truthfulness of the results of this study is determined by the degree of sincerity of the responses, who are graduates of the School of Educational Sciences in the first semester 2019/2020 as mentioned in the study..

\section{Previous studies}

Javan conducted a study (Javan, 2004) aimed to identify modern trends used to develop preparation programs for teachers in primary stage in Iran. Data were collected using two questionnaires, and found that a lot of teachers are not familiar with approaches and ways new in the preparation of teachers. There is limited communication or active interaction between the teachers of colleges and primary schools.

Abu Daqqa (2009) also conducted a study aimed at assessing the quality of academic programs at the Islamic University (Gaza) from the point of view of graduates, and data was collected through the distribution of a questionnaire to students Results showed that there are statistically significant differences attributable to the variable of academic specialization in the field of specialization courses.

Brownstein, Allan \& Veal (2009) also aimed to know what needs to be changed in pre-service science teacher preparation programs to obtain recognition by the National Council for Accreditation for teacher preparation NCATE . The study found the importance of providing a description of the priorities and competencies needed by teacher preparation programs Science (pre-service) in educational content, knowledge provided to students and teaching methods, and a learning environment to be recognized by NCATE.

Hamadneh conducted a study (2014) aimed at assessing the degree of availability of quality assurance standards in the primary education teacher preparation program at Yarmouk University from the viewpoint of students expected to graduate. The results of the study showed that the degree of availability of quality assurance standards in the primary education teacher preparation program at Yarmouk University came medium,. The results also showed that there were statistically significant differences between the averages of the responses of the sample individuals according to the cumulative average variable and came in favor of (very good and above).

Khidr and Abu Khalifa (2016) also conducted a study aimed at determining the degree to achieve some international professional standards and indicators of its performance among graduates of the Faculty of Educational Sciences in UNRWA from their viewpoint themselves.

The results of the study showed that the degree of graduates and new teachers possessing international professional standards was generally high with an average of 4.2 out of 5 . And there was no positive correlation statistically significant between the cumulative average of graduate students and the overall score on the scale.

Also (Rowan, Kline \& Mayer 2017) conducted a study aimed at knowing the evaluation of the new graduates from the teacher training program in Australia for the quality of their preparation in addition to the ability to teach students coming from various environments. The researchers used a questionnaire consisting of (46) items, and 
the student ratings ranged between 2.9 -3.6 out of 5. The researchers recommended that the methods of preparing teachers should be reviewed with regard to the axis of diversity among students.

Al-Ani et al. (2017) conducted a study aimed at revealing the degree of achievement of international accreditation standards CAEP in teacher preparation programs at the Faculty of Education at Sultan Qaboos University from the viewpoint of faculty members. The results of the study showed that the degree of achievement of CAEP standards in teacher preparation program at the College of Education was high, and also showed the absence of statistically significant differences in the degree of achievement of the criteria due to the type and academic rank.

Bawadi conducted a study (2017) aimed at identifying the quality of educational programs and administrative services at the Higher Institute for the preparation of teachers from the point of view of graduate students in the light of National Council For Accreditation Teacher Education (NCATE)standards. The researcher used the questionnaire as a study tool, and the study sample consisted of graduate diploma students, the results showed that the degree of availability Accreditation criteria ranged between weak and medium, and the presence of statistically significant differences among students according to the variable of specialization in favor of scientific versus humanities, and in favor of human specialization versus general specialization.

\section{Summary of previous studies and the scope of this study}

Through a review of previous studies, some of them are concerned with estimating the degree of availability of quality standards in the primary education teacher preparation program in the light of national standards or criteria prepared by researchers as in the Hammadna study (2014) and Abu Daqqa study (2009), or by developing primary school teacher preparation programs such as Javan study (2004), and other studies concerned with evaluating the application of NCATE standards in teacher preparation programs such as Brownstein, Alan and Phil (2009), and Bawadi study (2017). The rest of the studies were also interested in revealing the achievement of international accreditation standards CAEP in colleges of education such as the study of Al-Ani and others (2017).As for the study, Khader and Abu Khalifa (2016), it was interested in revealing the degree of verification of the standards (INTASC). The current study is different from all previous studies, as it used the latest and most famous international professional standards to prepare primary school teachers issued by CAEP in 2018 after its translation and editing.

\section{Study tool}

The researcher has prepared a scale depeding on CAEP standards which are published on the Foundation's website www.Caepnet.org. This scale provides a tool for measuring the degree of verifacation of CAEP standards for graduate students, which will help to reveal the strengths and weaknesses in the policies and procedures used in the School of educational sciences in the light of CAEP standards. The scale consists of (74) paragraphs distributed on five axes, the first axis comprising (17), and the second axis comprising (9) paragraphs, the third axis comprising (18) paragraphs and the fourth axis comprising (22) paragraphs and the fifth axis comprising (8) paragraphs. The degree of verification of each of the scale paragraphs was estimated from four degrees, where the response is given very high four degrees, the response is high three degrees, and the response is medium two degrees, while the response is weak, it is given one degree. The assessment of the degree of verification was adopted at three levels: high, medium and low, so that the score from 1-2 represents the low level, while the mark 2-3 represents the middle level, and the mark 3-4 represents the high level.

\section{Research methodology}

The study adopted the descriptive analytical approach in reaching the results, because this approach is appropriate to the nature of the current study

\section{Study population and sample}

The study population consisted of all graduate students in my specialty as a class teacher and raising a child in the first semester of the 2019/2020 college in the School of Educational Sciences, and they are (59) female students. The study sample consisted of all female students in the study community, of whom 57 students responded, and Table No.1 shows the distribution of the study sample according to specialization (class room teacher / child education). Table (1) shows the distribution of the study sample according to the variables of specialization, adjusted in High school, the cumulative average in the university and the desire to specialization. 
Table (1)

Distribution of samples according to the variables of specialization, the rate in the secondary general, the Cumulative at the university, and the desire to specialize

\begin{tabular}{|c|r|r|}
\hline Variables & Levels of change & The number \\
\hline Specialization & teacher Class & 36 \\
& Child Education & 21 \\
\hline Rate in high school & Good(70-76) & 15 \\
& good Very (77-84) & 18 \\
& Excellent(85-100) & 24 \\
\hline CumulativeAverage in university & Good(2.5-2.9) & 21 \\
& good Very(3-3.4) & 18 \\
& Excellent(3.5-4) & 18 \\
\hline The desire to specialization & & \\
& strong Not & 36 \\
\end{tabular}

Certify the tool of the study

The virtual and content validation for the scale has been verified. As for the apparent honesty, the scale was applied to a group of students from the Curricula and Teaching Department and reformulated the paragraphs that were not clear to them. As for the truthfulness of the content of the scale, the scale was presented to a group of faculty members in the college, and their opinion was taken about the clarity of language formulation, and the necessary adjustments were made to make the tool ready for application as in Appendix No. (1).

The stability of the tool

The scale stability coefficient was verified by calculating the Cronbach alpha coefficient, and its value was $(0.83)$, which is an appropriate indicator of the stability of the scale.

The results of the study and its discussion

Q 1: 1. What is the degree of verification of CAEP standards among classroom teacher and child eaducation graduates from the School of Educational Sciences at University of Jordan?

To answer this question ,arithematic mean and standard deviation for the degree of practicing CAEP standards for the graduates of School of Educational Sciences were calculated for complete tool and for each standard of the five study standards, and Table (2) shows these calculations .

.Table $(2)$

Arithematic mean and standard deviation for the degree of practicing CAEP standards for the the graduates of the School of Educational Sciences.

\begin{tabular}{|l|l|l|l|l|}
\hline $\begin{array}{l}\text { Standard } \\
\text { number }\end{array}$ & Standards & $\begin{array}{l}\text { Arithmetic } \\
\text { Average }\end{array}$ & $\begin{array}{l}\text { Standard } \\
\text { Deviation }\end{array}$ & Verification level \\
\hline 1 & $\begin{array}{l}\text { Understanding and Addressing Each Child's Developmental and } \\
\text { Learning Needs }\end{array}$ & 2.62 & 0.61 & Average \\
\hline 2 & $\begin{array}{l}\text { Understanding and Applying Content and Curricular Knowledge } \\
\text { for Teaching }\end{array}$ & 2.44 & 0.65 & Average \\
\hline 3 & Assessing, Planning, and Designing Contexts for Learning & 3.01 & 0.48 & Average \\
\hline 4 & Supporting Each Child's Learning Using Effective Instruction & 2.92 & 0.54 & Average \\
\hline 5 & Developing as a Professional & 2.29 & 0.75 & Low \\
\hline & Overall & 2.73 & 0.45 & Average \\
\hline
\end{tabular}

It is clear from Table No. (2) that:

1- The degree of verification of (CAEP) standars for graduates of class room teacher and child education was estimated with an average score of (2.75) and corresponds to an average degree of verification.

2- The descending order of CAEP standaerds according to the degree achieved by graduates from their point of view, as follows: : at first ,the standard "Assessing, Planning, and Designing Contexts for Learning " with an arithmetic average (3.01) and corresponds to a high degree of verification, second the standard" "Supporting Each Child's Learning Using Effective Instruction "with an average of (2.92) and corresponds to a Medium degree of verification, then the standard" Understanding and Addressing Each Child's Developmental and Learning Needs "with an average of 2.62 and corresponds to an average degree of verification, then the standard "Understanding 
and Applying Content and Curricular Knowledge for Teaching" with average (2.44) and corresponding Medium degree of verification, then the standard "Developing as a Professional", which came in last place with an average (2.29) and corresponds to a low degree of practice.This result corresponds to the results of the Javan studies (2004) and Hamadanah (2014), where the degree of achievement of the CAEP standards ranged between medium and weak, and contradicted the results of Abu Daqqa (2009), Al-Ani (2017), Khadr and Abu Khalifa (2016) where their degrees meet high standards, perhaps due to the fact CAEP standards are new standards, and more time and effort needed to be achieved a high degree, while the degree to which the national standards or the standars developed by researchers were high, as they are known and used. As for the study of Khader and Abu Khalifa (2016), their high results may due to special reasons related to develop their courses according to international standards.

Q 2: Are there statistically significant differences (at the level of $\alpha \leq 0.05$ ) in the degree of verification of CAEP standards among the graduates from School of educational Sciences at University of Jordan due to their specialization? This question was answered by:

A- Extracting the mean and standard deviations to the degree that the standards are met on the instrument in full according to the variable of specialization. Table (3) shows these results.

Table(3)

Mean and standard deviations Estimates of the graduates of the College of Education for their degree of practicing Cape standards Depending on the specialty variable (ClassTeacher / Child Education )

\begin{tabular}{|l|l|l|l|l|l|l|}
\hline Specialization & Number & Mean & $\begin{array}{l}\text { Standard } \\
\text { deviation }\end{array}$ & T & $\begin{array}{l}\text { Degrees } \\
\text { freedom }\end{array}$ & $\begin{array}{l}\text { Level } \\
\text { Significance }\end{array}$ \\
\hline $\begin{array}{l}\text { Classroom } \\
\text { teacher }\end{array}$ & 36 & 2.79 & .42 & 1.22 & 55 & 0.229 \\
\hline Child Education & 21 & 2.64 & .5 & & & \\
\hline
\end{tabular}

it is noted from Table (3) that there are no statistically significant differences in the degree of verification of CAEP standards on the tool as a whole, among the graduates of the School of Educational Sciences attributed to their specialty (class teacher / child education).

B- Extracting means and standard deviations to the degree that each of the instrument's standard is achieved according to the specialty variable. Table (4) shows these results.

Table(4)

Arithmetic averages and standard deviations to the degree that each of the instrument's standard is met according to the specialty variable

\begin{tabular}{|c|c|c|c|c|c|c|}
\hline Specialization & \multicolumn{3}{|c|}{ Classroom Teacher } & \multicolumn{3}{|c|}{ Child Education } \\
\hline Standards & Number & Average arithmetic & Standard deviation & Number & Average arithmetic & Standard deviation \\
\hline $\begin{array}{l}\text { 1- Understanding and } \\
\text { Addressing Each Child's } \\
\text { Developmental and } \\
\text { Learning Needs }\end{array}$ & 36 & 2.72 & 0.6 & 21 & 2.44 & 0.59 \\
\hline $\begin{array}{l}\text { 2-Understanding and } \\
\text { Applying Content and } \\
\text { Curricular Knowledge } \\
\text { for Teaching }\end{array}$ & 36 & 2.59 & 0.62 & 21 & 2.19 & 0.65 \\
\hline $\begin{array}{l}\text { 3- Assessing, Planning, } \\
\text { and Designing Contexts } \\
\text { for Learning }\end{array}$ & 36 & 3.06 & 0.45 & 21 & 2.94 & 0.52 \\
\hline $\begin{array}{l}\text { 4- Supporting Each } \\
\text { Child's Learning Using } \\
\text { Effective Instruction }\end{array}$ & 36 & 2.89 & 0.52 & 21 & 2.95 & 0.59 \\
\hline $\begin{array}{l}\text { 5- Developing as a } \\
\text { Professional }\end{array}$ & 36 & 2.35 & 0.71 & 21 & 2.18 & 0.81 \\
\hline
\end{tabular}

It is noted from Table (4) that there are apparent differences between the arithmetic averages and standard deviations on the sub- criteria of the instrument according to the specialty variable. To reveal the significance of 
these differences, the results of the multiple variance analysis were extracted. Table No. (5) shows these results.

Table (5)

Results of multiple variance analysis to reveal the significance of the differences between the arithmetic averages and the standard deviations between class teacher responses and child rearing on the sub criteria of the study tool

\begin{tabular}{|c|c|c|c|c|c|c|}
\hline Source of contrast & Standards & $\begin{array}{l}\text { Sum } \\
\text { of squares }\end{array}$ & $\begin{array}{l}\text { Degrees } \\
\text { of freedom }\end{array}$ & Average squares & F. & Significance level \\
\hline \multirow{5}{*}{ Specialization } & $\begin{array}{l}\text { Understanding and Addressing } \\
\text { Each Child's Developmental and } \\
\text { Learning Needs }\end{array}$ & 1.07 & 1 & 1.074 & 2.988 & 0.09 \\
\hline & $\begin{array}{l}\text { Understanding and Applying } \\
\text { Content and Curricular } \\
\text { Knowledge for Teaching }\end{array}$ & 2.08 & 1 & 2.078 & 5.223 & 0.026 \\
\hline & $\begin{array}{l}\text { Assessing, Planning, and } \\
\text { Designing Contexts for Learning }\end{array}$ & 0.2 & 1 & 0.199 & 0.874 & 0.354 \\
\hline & $\begin{array}{lrr}\text { Supporting } & \text { Each } & \text { Child's } \\
\text { Learning } & \text { Using } & \text { Effective } \\
\text { Instruction } & & \end{array}$ & 0.04 & 1 & 0.044 & .147 & 0.703 \\
\hline & Developing as a professional & 0.41 & 1 & 0.409 & 0.733 & 0.396 \\
\hline \multirow{5}{*}{ The error } & $\begin{array}{l}\text { Understanding and Addressing } \\
\text { Each Child's Developmental and } \\
\text { Learning Needs }\end{array}$ & 19.78 & 55 & 0.36 & & \\
\hline & $\begin{array}{l}\text { Understanding and Applying } \\
\text { Content and Curricular } \\
\text { Knowledge for Teaching } \\
\end{array}$ & 21.88 & 55 & 0.398 & & \\
\hline & $\begin{array}{l}\text { Assessing, Planning, and } \\
\text { Designing Contexts for Learning }\end{array}$ & 12.55 & 55 & 0.228 & & \\
\hline & $\begin{array}{lrr}\text { Supporting } & \text { Each } & \text { Child's } \\
\text { Learning } & \text { Using } & \text { Effective } \\
\text { Instruction } & & \end{array}$ & 16.57 & 55 & 0.301 & & \\
\hline & Developing as a professional & 30.69 & 55 & 0.558 & & \\
\hline \multirow{5}{*}{ Overall } & $\begin{array}{l}\text { Understanding and Addressing } \\
\text { Each Child's Developmental and } \\
\text { Learning Needs }\end{array}$ & 20.85 & 56 & & & \\
\hline & $\begin{array}{l}\text { Understanding and Applying } \\
\text { Content and Curricular } \\
\text { Knowledge for Teaching }\end{array}$ & 23.96 & 56 & & & \\
\hline & $\begin{array}{l}\text { Assessing, Planning, and } \\
\text { Designing Contexts for Learning }\end{array}$ & 12.75 & 56 & & & \\
\hline & $\begin{array}{lrr}\text { Supporting } & \text { Each } & \text { Child's } \\
\text { Learning } & \text { Using } & \text { Effective } \\
\text { Instruction } & & \end{array}$ & 16.61 & 56 & & & \\
\hline & Developing as a professional & 31.1 & 56 & & & \\
\hline
\end{tabular}

It is noted from Table (5) that there are no statistically significant differences in the degree of verification of CAEP standards among graduates of School of Educational Sciences, attributed to the specialty (classroom teacher / child education). This result is consistent with the results of Nawafleh and Najadat studies (2014), which showed that there are no statistically significant differences in the estimates of students according to their specialization (class teacher / child education). Perhaps this is due to the similarity of class teacher students and child education in the specialty because it falls within the disciplines of humanities, in addition to the similarity of the educational environment in the college and the training environment in schools. This result differed with the Bawadi study, which showed that there are statistically significant differences between students 'estimates according to the variable of specialization in favor of scientific versus humanism and in favor of human specialization versus general specialization. Perhaps these differences are due to the difference in the nature of disciplines: scientific, humanitarian, and general.

Q 3- Is there a statistically significant correlation (at $\alpha \leq 0.05$ ) between the degree of verification of CAEP standards among graduates of the School of Educational Sciences and their rates in high school? 
To answer this question, the Pearson correlation coefficient was calculated between graduate students 'grades on each of the criteria, the overall score on the instrument, and their rates in high school. Table (6) shows these results. Table(6)

Pearson's correlation between the estimates of graduates of School of Educational Sciences for their degree of practicing CAEP standards and their rate in high school

\begin{tabular}{|c|c|c|}
\hline Standards & $\begin{array}{l}\text { Correlation coefficient } \\
\text { of rate in high school }\end{array}$ & Significance level \\
\hline $\begin{array}{l}\text { Understanding and Addressing Each Child's Developmental and } \\
\text { Learning Needs }\end{array}$ & -0.02 & 0.875 \\
\hline $\begin{array}{l}\text { Understanding and Applying Content and Curricular Knowledge } \\
\text { for Teaching }\end{array}$ & -0.07 & 0.617 \\
\hline Assessing, Planning, and Designing Contexts for Learning & -0.04 & 0.754 \\
\hline Supporting Each Child's Learning Using Effective Instruction & 0.02 & 0.911 \\
\hline Developing as aProfessional & 0.08 & 0.571 \\
\hline Overall & -0.02 & 0.904 \\
\hline
\end{tabular}

It is noted from Table (6) that there is no statistically significant correlation between the estimates of the graduates of School of Educational Sciences in the degree of their practice of CAEP standards on each of the standards and on the complete tool and the rate in high school. The correlation coefficients were weak and close to zero. This result can be attributed to the fact that graduate students 'high school enrollment rates are generally high and above $75 \%$ average. There were no studies that matched its results or contradicted this result from among the previous studies that were reviewed in this study, as none of them discussed the relationship between the degree of verification of standars and the rate in high school

Q4- Is there a statistically significant correlation (at $\alpha \leq 0.05$ ) between the degree of verification of CAEP standards among graduates from the School of Educational Sciences and their cumulative rates at university?

To answer this question, the Pearson correlation coefficient was calculated between the graduates students 'grades on each of the standards and the overall degree on the tool and the cumulative averages at the university. Table (7) shows these results.

Table (7)

Pearson correlation values between the estimates of graduates of the School of Educational Sciences for their degree of practicing CAEP standards and their cumulative averages at the university.

\begin{tabular}{|l|l|l|}
\hline \multicolumn{1}{|c|}{ Standards } & \multicolumn{2}{c|}{} \\
\cline { 2 - 3 } & $\begin{array}{l}\text { Correlation coefficient } \\
\text { of cumulative average }\end{array}$ & Significance level \\
\hline $\begin{array}{l}\text { Understanding and Addressing Each Child's Developmental and } \\
\text { Learning Needs }\end{array}$ & -0.06 & 0.673 \\
\hline $\begin{array}{l}\text { Understanding and Applying Content and Curricular Knowledge for } \\
\text { Teaching }\end{array}$ & -0.17 & 0.209 \\
\hline Assessing, Planning, and Designing Contexts for Learning & -0.06 & 0.642 \\
\hline Supporting Each Child's Learning Using Effective Instruction & 0.03 & 0.797 \\
\hline Developing as a Professional & -0.11 & 0.435 \\
\hline Overall & -0.08 & 0.532 \\
\hline
\end{tabular}

It is noted from Table (7) that there is no positive and statistically significant correlation between the cumulative average and the degree to which each standard achieved and the whole instrument. The correlation coefficients were weak and approached zero. This result is consistent with the result of the Khidr and Abu Khalifa study (2016), 
and may be due to the fact that graduates students have high and convergent rates in general, while they conflict with the results of the Hammadna study (2014) where the results showed a correlation relationship between the responses of the individuals of the sample according to the cumulative average variable It came in favor (very good and above).

Q 5: Is there a statistically significant correlation (at $\alpha \leq 0.05)$ between the degree of verification of CAEP standards among graduates from School of Educational Sciences and their desire to specialize in the university?

To answer this question, the value of the Chi-Square Test was extracted, and Table (8) shows a positive correlation between the degree of verification of CAEP standards for the students and their desire to their specialization in the university. And this result did not agree or differ with the results of previous studies that It was reviewed in this study, as none of them examined the relationship between the degree of verification of the preparation standards and the desire of students specialization in the university.

Chi-Square Test

\begin{tabular}{|c|l|l|}
\hline The value of Chi square & Degrees of freedom & Significance level \\
\hline 4.095 & 1 & 0.043 \\
& & \\
\hline
\end{tabular}

This result may be due to the fact that the degree for verification of standards was low for $76 \%$ of graduates students with a strong desire to their specialization. As shown in Table No (9).

Table (9)

Percentage for verification of standards for graduate students according to the desire to specialization

\begin{tabular}{|c|c|c|c|c|c|}
\hline \multirow[b]{2}{*}{$\begin{array}{r}\text { The desire } \\
\text { to specializ } \\
\text { ation }\end{array}$} & & & & & \multirow[b]{2}{*}{ Tota } \\
\hline & $\begin{array}{c}\text { The number of the } \\
\text { lower } \\
\text { category students }\end{array}$ & $\begin{array}{r}\text { The percentage of } \\
\text { lower category }\end{array}$ & $\begin{array}{l}\text { The number of the } \\
\text { high category students }\end{array}$ & $\begin{array}{l}\text { The percentage } \\
\text { of } \\
\text { the higher catego } \\
\text { ry }\end{array}$ & \\
\hline Not strong & 22 & $76 \%$ & 14 & $50 \%$ & 36 \\
\hline Strong & 7 & $24 \%$ & 14 & $50 \%$ & 21 \\
\hline Total & 29 & $100 \%$ & 28 & $100 \%$ & 57 \\
\hline
\end{tabular}

The enrollment of graduate students in the specialization of classroom teacher and child education may be due to social reasons, or for reasons related to the lack of other options available to female students for admission to colleges or majors that require higher rates.

\section{Recommendations:}

1- Development of teacher education programs at School of Educational Sciences to comply with CAEP standards. 2- Amending the policy of accepting students in the specialties of the classroom teacher and child education so that those who have a strong desire in the teaching profession are selected in addition to a high average in the high school.

\section{Arabic reference:}

-Ababneh, Saleh (2015) evaluating the quality of the performance of the Faculty of Science Education in the light of the standards " Ankit " to adopt the institutions of the preparation of teachers from the point of view of the members of the body of teaching, studies, science education 42(3):767-784

-Bawadi, Salem(2017. An evaluation study of teacher preparation programs and services provided at the Higher Institute for Teachers in Mukalla in light of accreditation standards ) NCA TE (From the point of view of the graduates . Al - Andalus Journal for Humanities and Social Sciences . P (14) (vol) .(15)

Al - Duwairi, Khadija, (2015) Evaluation of Education Technical in the city

of Albertmj training pain Introduction for teachers of Jeddah , Kingdom of Saudi Arabia . un 
published, Masterthesis University of Umm Qura, Mecca, Saudi Arabia.

-Accuracy, Sana 2009 ,evaluating

of programs Academy University Islamic Gaza . Journal of Educational and

the quality Psychological Sciences, Volume 10

Al -Da'jah , Hisham , Al -Saaideh et al , .2011 ,Evaluation of the Professional Diploma in Education Program at the University of Jordan , (38) (6)

-Hamdan, Muhammad Ziyad, 1997 ,Field Practical Education - Concepts ,Competencies and School Applications , Modern Education H ouse, $\mathrm{p} 4$.

Al -Saud, Ratib , 2002,Total Quality Management : A suggested model for developing school administration in Jordan . Da mascus University Journal,

Khatib , Mohammed , 2007 ,the entrance to the application of standards and systems of quality overall in the institutions of educational , meeting the annual Fourth th Assembly of the Saudi Science Altriueh and psychological - Quality in Education General - Saudi Arabia

-Canaan, Ahmed , 2009 ,Evaluating Teacher Education Programs and Their Outputs according to Quality Standards from the Point of View of Fourth Year Students in the Class Teacher Class and Members of the Educational Authority , Damascus University Journal ,25 (3+4) p.16-93

-Abu Orabi, Sultan( 2018)(Conference on Education of Higher in the homeland of the Arab in the light of the challenges and changes the world . Zarqa University . Jordan.

-Khader, Ghazi , Abu Khalifa , Ibtisam meets some international professional standards and performance indicators for graduates the Faculty of Educational Sciences and University Literature in UNRWA from their viewpoint themselve S

Al-Darij, Muhammad (2016), Standards in Education : models and experiences to ensure the quality of education, from the Internet

-Governorate, Sameh( 2014 )The Effective Future Teacher : Criteria for its Preparation, Qualification ,and Traits - Al -Rai Newspaper http://alrai.com/article/683245.html

-Kaabi , Naima) , (2004)level check content when children primer in kindergarten children in the Kingdom of Bahrain , a message Ph.D .is unpublished, University of Jordan , Jordan

-Wah , Muhammad Abdul -Razzaq Ibrahim) (2003)The teacher training system $\quad$ is $\quad$ organized in light of the comprehensive quality standards . Amman Daral feker , p16.

-Dahshan , Jamal (2007) " standards to ensure quality and accreditation in education quality in Egypt and the homeland of the Arab ", the paper work submitted in the Conference Scientific Annual Second, Faculty of Education Quality, University of Mansoura.

-Auda, Ahmed( 2011) Quality assurance standards derived from those affected by the results of evaluation in the school : a rooted approach to stimulate accreditation and quality. Journal of Jordan in science education, volume 7 ,number2 ,163-194

-Nawafleh, Walid, Nejadat, Ahmed (2014).(Evaluate the effectiveness of the program to prepare teachers education elementary at the University of Yarmouk in the light of the standards of national for the development of the teacher professionally from beer view students . Journal of the University of Success Research Science Human Folder(2)28

Al -Ani , Wajiha, Ahmed, Azzam

,Al -Abri, Khalaf (2018) .Degree of achievement of international accreditation standards ) CAEP (In the programs of the preparation of the teacher at the University

of Sultan Qaboos . Journal of Jordan in science education, volume 14 ,number 283-300.

-UNESCO(2017)The reality of teacher preparation programs in the Arab world. The Regional Center for Quality and Excellence in Education.

English references:

-David, L,. (2002) .Making a Difference Through Teacher Education. Paper Presented in Teacher Education Conference, Birmingham, Alabama, October 14-17.

-Higginson, FL (1966) And the Global Roles .Teachers Change.The $45 \mathrm{Th}$ of the Session Of The International Conference On Education (Unesco of Geneva, 30Sep-5Oct.

-Rowan, Leonie; Kline, Jodie; Mayer, Diane. (2017). Early Career Teachers' Perceptions of Their Preparedness to Teach "Diverse Learners": Insights from an Australian Research Project. Australian Journal of Teacher Education Vol 42, 10.

- Popham, J. (2015) .Does CAEP Have it Right? An Aanalasis of The Impact of The Diversity of Field Placements on Elementary CandidatsTeacher Performance Assessments Completed During Student 
Teaching https://scholarsarchive.byu.edu/cgi/viewcontent.cgi? article $=6561 \&$ context $=$ etd

-Armstrong, DonnaM. (2007) “Acase Study of the Effectiveness of a Teacher Education Program. SotLCommons Conference . 9 .

https: // digitalcommons.georgiasizontal .edu / sotlcommons / SoTL / 2007/9

-Javan, M. (2004) .Improving Pre-serviceElementary Teacher Education In The Islamic Republic of Iran. Dissertation Abstract International-A64 / 10, P.3649.

- www.Caepnet.org

- Davies, 1. (1991) .Addence of Quality: Full Time Initial Teacher Courses> Journal of Further and Higher Education, 159 (1), 21-25.

-Martin, H. (1991). The Dimensions of Excellence in Programs of Teacher Education. Annual Conference Padre Island, Texas.

\section{- Appendix (1)}

The researcher is conducting a study entitled " The Degree of Verification of CAEP standards Concerning Graduates of School of Educational Sciences From their Point Of View at the University of Jordan "

And for the importance of your opinions, please kindly answer carefully and objectively to the paragraphs of the questionnaire, as the data will be dealt with for the purposes of scientific research only. Thank you for your cooperation and interest. Accept my sincere respect and appreciation.

- Please fill the following information :

The researcher

The rate in the High school

Specialization of student -teacher

Classroom teacher

Cumulative average

The desire to specialize :
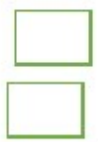

child hood education

, not strong 


\begin{tabular}{|c|c|c|c|c|c|}
\hline \multicolumn{4}{|c|}{ Level of performance } & \multicolumn{2}{|l|}{ Standards } \\
\hline $\begin{array}{l}\text { Very hig } \\
\text { h } \\
4\end{array}$ & $\begin{array}{l}\text { High } \\
3\end{array}$ & $\begin{array}{l}\text { Medium } \\
2\end{array}$ & $\begin{array}{l}\text { A few } \\
1\end{array}$ & $\begin{array}{l}\text { Understanding and Addressing Each } \\
\text { Child's Developmental and Learning } \\
\text { Needs }\end{array}$ & $\begin{array}{l}\text { The } \\
\text { first } \\
\text { stan } \\
\text { dard }\end{array}$ \\
\hline \multicolumn{6}{|c|}{$\begin{array}{l}\text { A - .use knowledge of how the growth of children and learning in the planning experiences } \\
\text { of learning appropriate to take into account aspects of the strengths and weaknesses of each child }\end{array}$} \\
\hline & & & & $\begin{array}{l}\text { 1- I seek to know students 'preferences } \\
\text { and interests and } \\
\text { use knowledge to plan appropriate lea } \\
\text { rning experiences }\end{array}$ & \\
\hline & & & & $\begin{array}{l}\text { 2- I am conducting a case study to } \\
\text { know and } \\
\text { understand the strengths and needs } \\
\text { of each child }\end{array}$ & \\
\hline & & & & $\begin{array}{l}\text { 3- Design individual learning experien } \\
\text { ces for small groups and at } \\
\text { the class level }\end{array}$ & \\
\hline & & & & $\begin{array}{l}\text { 4- I use the results } \\
\text { of students to guide teaching }\end{array}$ & \\
\hline \multicolumn{6}{|c|}{$\begin{array}{l}\text { B - understand and use the principle of differences of individual between the students and } \\
\text { the different families and } \\
\text { of learning comprehensive based on the points of strengths and weaknesses }\end{array}$} \\
\hline & & & & $\begin{array}{l}\text { 5. deafen and enforced plans } \\
\text { for teaching include the options varied } \\
\text { content and procedures build on } \\
\text { the interests of students and } \\
\text { the diversity of their families. }\end{array}$ & \\
\hline & & & & $\begin{array}{l}\text { 6. I share with } \\
\text { a teacher chapter or specialist in supp } \\
\text { ort of learning a child does not speak } \\
\text { the language Arabic }\end{array}$ & \\
\hline \multicolumn{6}{|c|}{ C - Working with children's families to enhance each child's motivation } \\
\hline & & & & $\begin{array}{l}\text { 7- I seek to know } \\
\text { the interests and talents } \\
\text { of children so that I can enhance } \\
\text { the learning motivation of students wi } \\
\text { th low motivation. }\end{array}$ & \\
\hline & & & & $\begin{array}{l}\text { 8- I use the family of a student } \\
\text { to complete his case study to } \\
\text { support his learning and } \\
\text { development in the coming year }\end{array}$ & \\
\hline & & & & $\begin{array}{l}\text { 9- I } \\
\text { am preparing a continuous communic } \\
\text { ation plan with the families of students } \\
\text { of various cultures and environments }\end{array}$ & \\
\hline \multicolumn{5}{|c|}{$\begin{array}{l}\text { Understanding and Applying Content and } \\
\text { Curricular Knowledge for Teaching }\end{array}$} & $\begin{array}{l}\text { The } \\
\text { seco } \\
\text { ndst } \\
\text { anda } \\
\text { rd }\end{array}$ \\
\hline
\end{tabular}




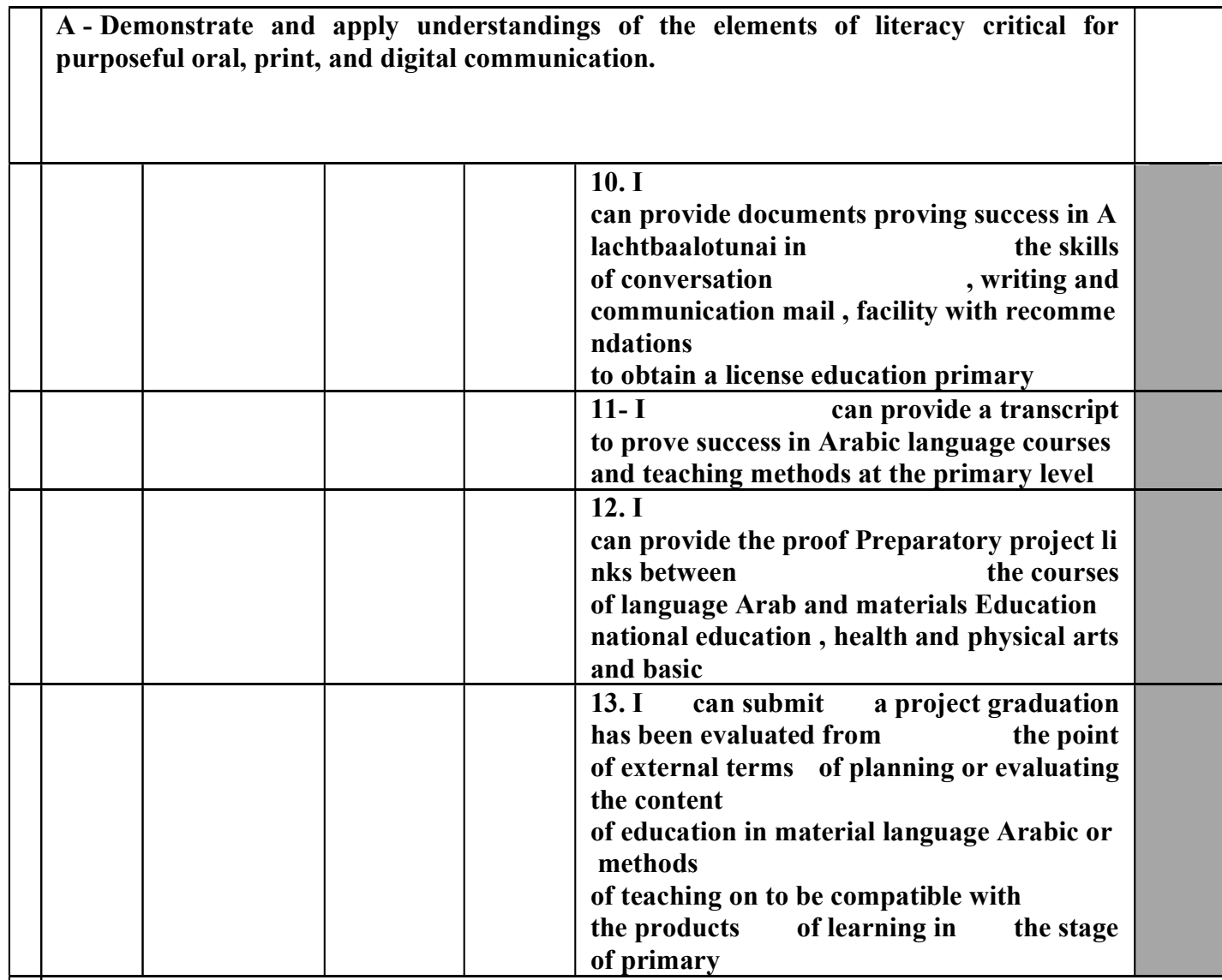

B- Demonstrate and apply understandings of major mathematics concepts, algorithms, procedures, applications and mathematical practices in varied contexts, and connections within and among mathematical domains

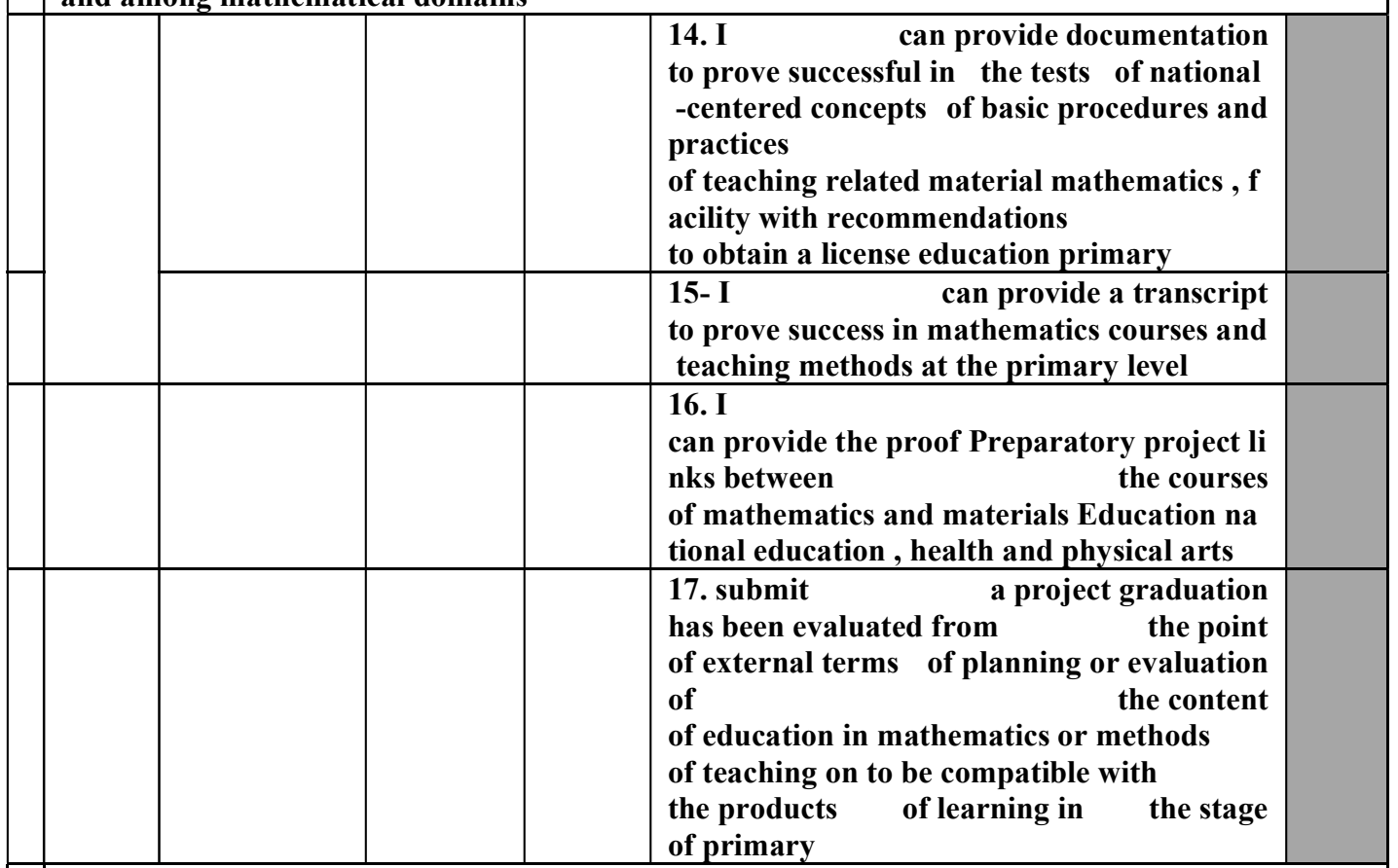

C-Demonstrate and apply understandings and integration of the three dimensions of science and engineering practices, cross-cutting concepts, and major disciplinary core ideas, within the major 


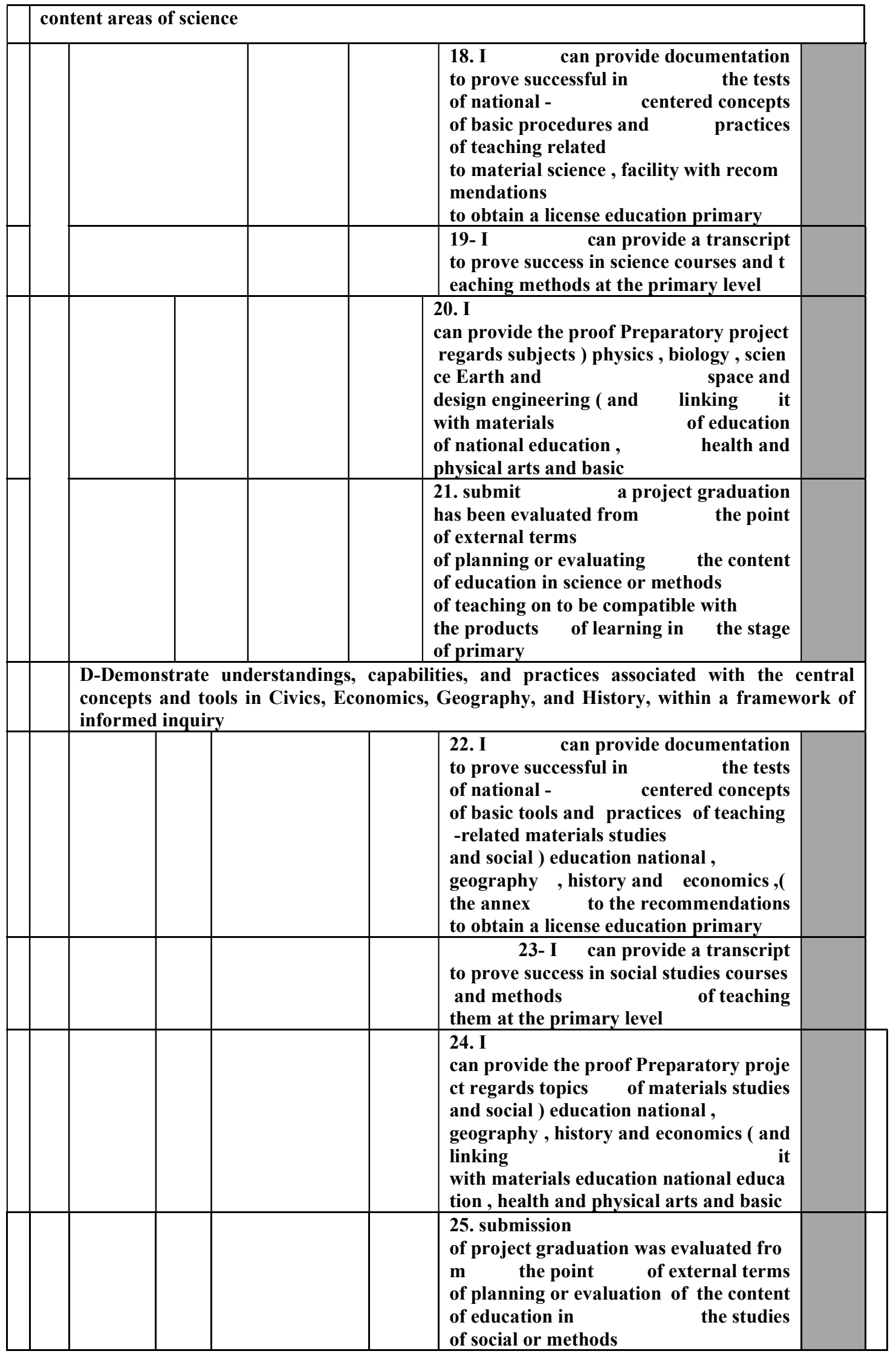




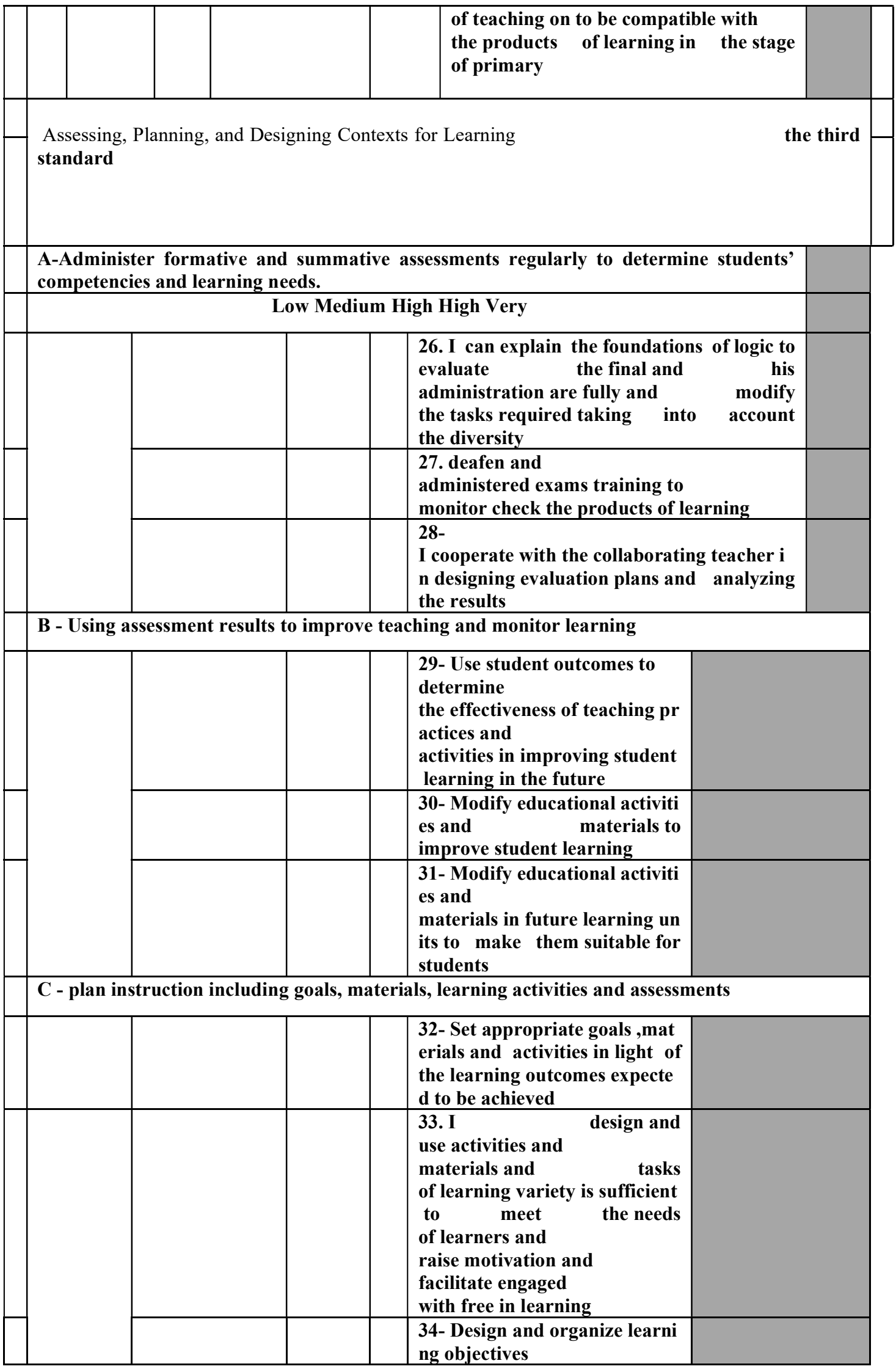




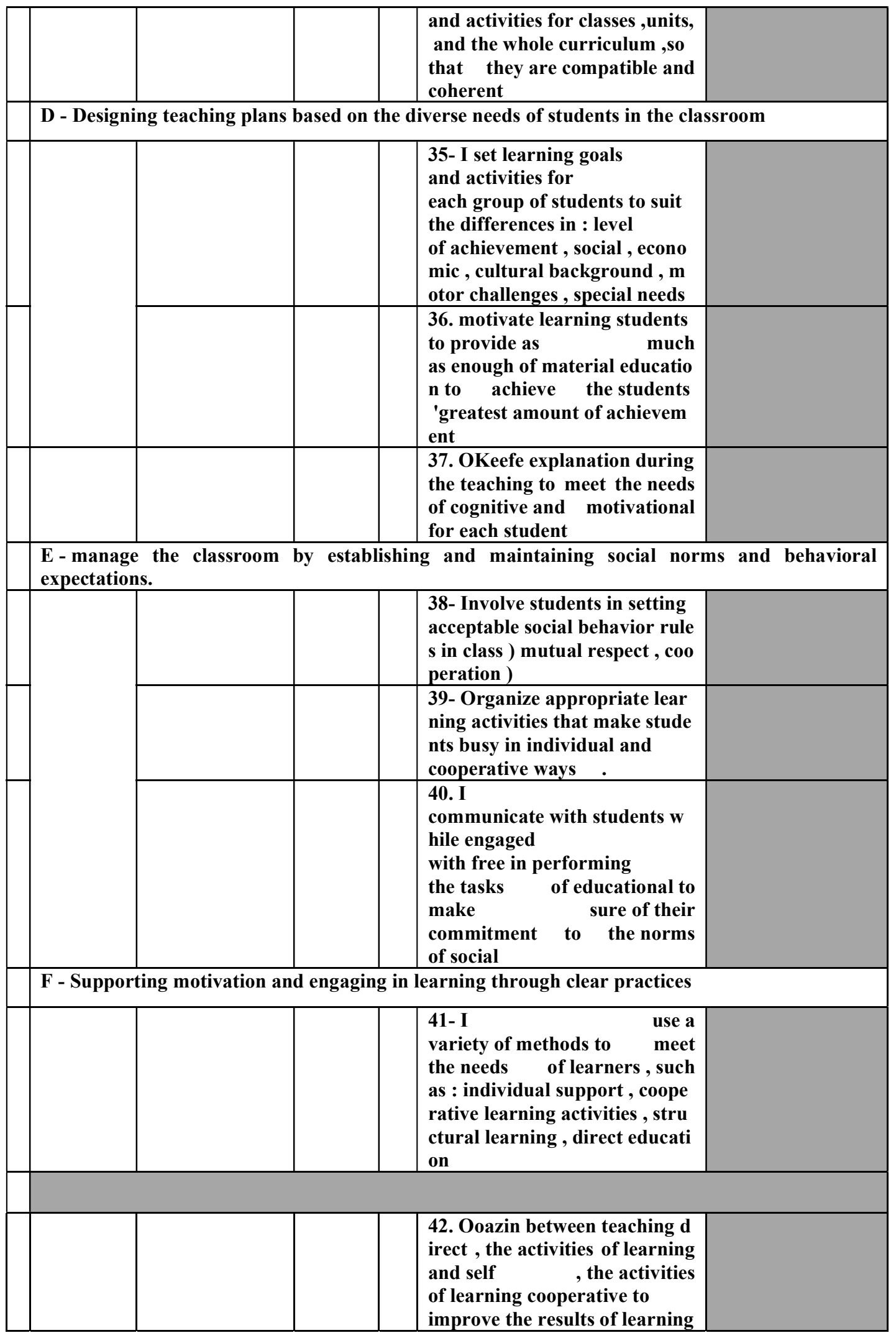




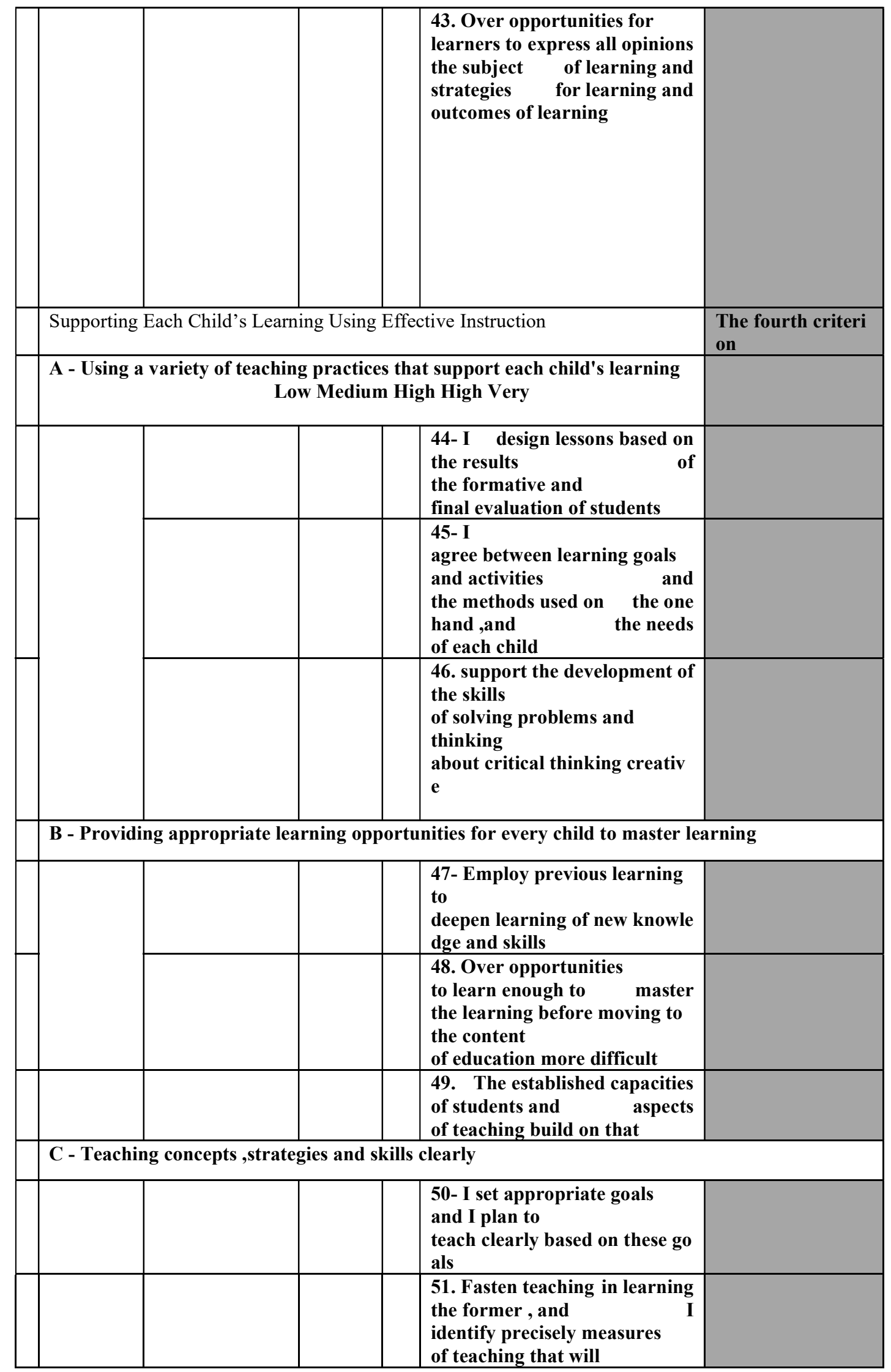




\begin{tabular}{|l|l|l|l|l|}
\hline & & $\begin{array}{l}\text { lead to learn the knowledge } \\
\text { of new }\end{array}$ & \\
\hline & & $\begin{array}{l}\text { 52- I monitor the impact of } \\
\text { a teaching on student learning } \\
\text { by } \\
\text { using appropriate assessment t } \\
\text { ools } \\
\text { and adjust teaching based on a } \\
\text { ssessment results . }\end{array}$ & \\
\hline
\end{tabular}

D - Provide students with constructive feedback to improve their enhance their motivation and participation

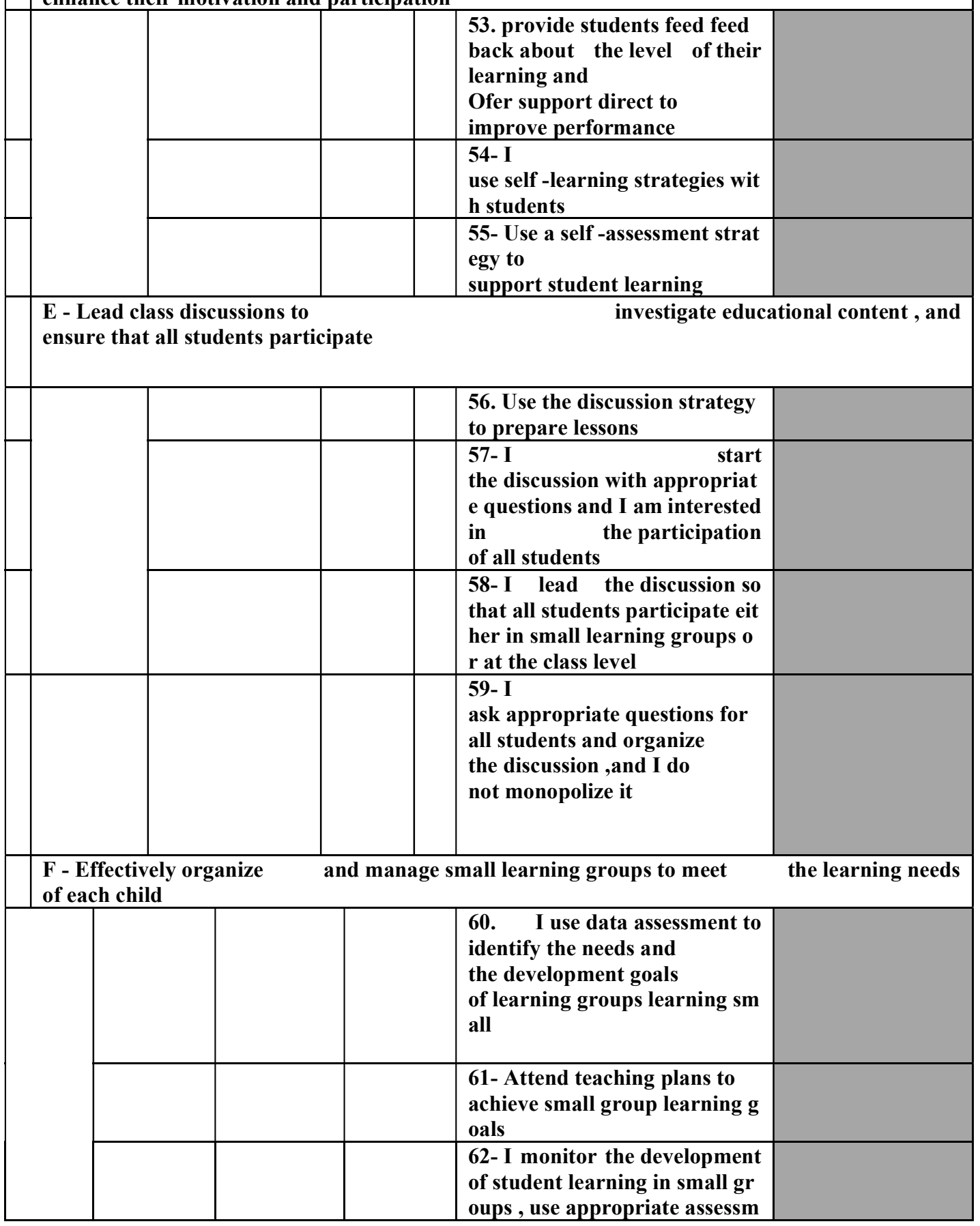




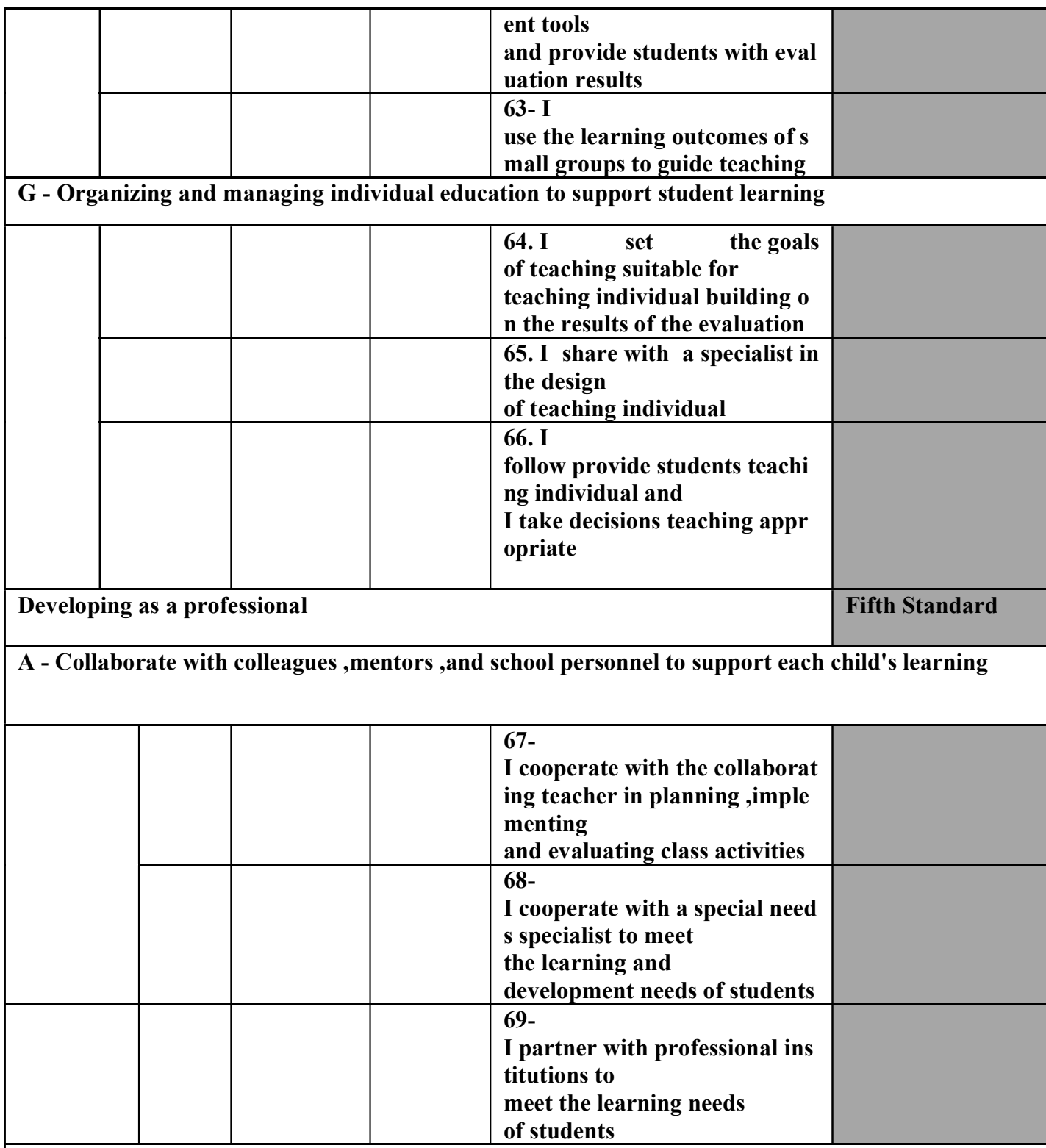

B - Developing professional performance based on analysis of student results, self -reflection, nati onal professional standards, and research results

\begin{tabular}{|l|l|l|l|l|}
\hline & & $\begin{array}{l}\text { 70. deafen and } \\
\text { clenching activities } \\
\text { the development } \\
\text { of professional compatible wit } \\
\text { h the research current }\end{array}$ & \\
\hline & & $\begin{array}{l}\text { 71- } \\
\text { I amend professional develop } \\
\text { ment activities after practicing } \\
\text { self -reflection based on } \\
\text { the results of student assessme } \\
\text { nt }\end{array}$ & \\
\cline { 2 - 6 } & & $\begin{array}{l}\text { 72. I } \\
\text { participate in attending works } \\
\text { hops trained professional such } \\
\text { as schools safe to protect }\end{array}$ & \\
\hline
\end{tabular}




\begin{tabular}{|l|l|l|l|l|}
\hline & & & $\begin{array}{l}\text { the child from abuse, dealing } \\
\text { with cultures multiple, cycles } \\
\text { of ownership of intellectual . }\end{array}$ & \\
\hline $\begin{array}{l}\text { C - Collaborate with peers } \\
\text { enhance student learning }\end{array}$ & & \multicolumn{3}{|c|}{ of teachers to } \\
\hline & and with professional associations & $\begin{array}{l}\text { 73. belonged to institutions } \\
\text { of professional and prove how } \\
\text { it contributes } \\
\text { to this in improving } \\
\text { the learning of students }\end{array}$ & \\
\hline & & $\begin{array}{l}\text { 74. I attended workshops wor } \\
\text { k or seminars or conferences a } \\
\text { nd } \\
\text { it contributes } \\
\text { to this in improving } \\
\text { the learning of students }\end{array}$ & \\
\hline
\end{tabular}

